\title{
Analisis Efektivitas Pelaksanaan Pendidikan Jarak Jauh (PJJ) Selama Pandemi COVID-19 Pada Mahasiswa Semester II Program Studi Pendidikan Olahraga Dan Kesehatan Tahun Ajaran 2020/2021
}

\author{
${ }^{1}$ Supriadin, ${ }^{2}$ Nune Wire Panji Sakti \\ ${ }^{12}$ Dosen Universitas Pendidikan Mandalika \\ supriadin@undikma.ac.id
}

\begin{abstract}
Abstrak. Tujuan penelitian ini adalah untuk menganalisis efektivitas pelaksanaan proses Pendidikan Jarak Jauh (PJJ) selama pandemi Covid-19 pada mahasiswa semester II program studi Pendidikan Olahraga dan Kesehatan Tahun Ajaran 2020/2021. Penelitian ini menggunakan metode campuran. Teknik pengumpulan data yang digunakan adalah angket yang diberikan kepada mahasiswa sebulan sekali. Subjek penelitian ini adalah mahasiswa semester II program studi Pendidikan Olahraga dan Kesehatan. Berdasarkan hasil penelitian yang dilakukan dengan pengisian angket, secara umum pelaksanaan Pendidikan Jarak Jauh (PJJ) pada mahasiswa semester II program studi Pendidikan Olahraga dan Kesehatan perkuliahan cukup efektif dengan persentase 60-79\%. Hasil angket pelaksanaan perkuliahan PJJ yang memiliki keefektifan buruk dengan kriteria 48\% sedang dalam proses evaluasi. Disarankan dalam Pendidikan Jarak Jauh (PJJ), Dosen dituntut mampu merancang kegiatan perkuliahan dari perencanaan hingga evaluasi dengan cara yang lebih sederhana, lebih kreatif dan efektif.
\end{abstract}

Kata Kunci: Covid-19, Akses Perkuliahan Jarak Jauh.

\section{PENDAHULUAN}

Berdasarkan peraturan menteri pendidikan dan kebudayaan Republik Indonesia nomor 24 tahun 2012 tentang penyelenggaraan pendidikan jarak jauh pada pendidikan tinggi. Kondisi pandemi Covid-19 telah mempengaruhi hampir seluruh aspek kehidupan manusia. Untuk memutus mata rantai penularan virus tersebut, banyak pembatasan yang dilakukan oleh pemerintah, termasuk pemerintah Indonesia. Pendidikan anak sekolah dasar adalah salah satu sektor yang sangat terdampak kondisi pandemi ini. Sampai saat ini, kemendikbud masih belum mengijinkan pemerintah daerah di selain zona kuning dan hijau untuk membuka sekolah. Dalam rangka pemenuhan hak peserta didik untuk mendapatkan layanan pendidikan selama darurat penyebaran Corona Virus Disease (COVID-19), proses pembelajaran dilaksanakan melalui penyelenggaraan Pendidikan Jarak Jauh (PJJ) sebagaimana tercantum dalam Surat Edaran Kemendikbud Nomor 4 Tahun 2020 tentang Pelaksanaan Kebijakan Pendidikan dalam Masa Darurat Penyebaran Corona Virus Disease (COVID-19) yang diperkuat dengan Sekjen Nomor 15 tahun 2020 tentang Pedoman Pelaksanaan BDR selama darurat Covid 19.
Prinsip dari Kegiatan Pendidikan Jarak Jauh (PJJ) ini adalah mahasiswa dapat mengakses materi dan sumber pembelajaran tanpa batasan waktu dan tempat. Kegiatan Pendidikan Jarak Jauh (PJJ), ini diharapkan dapat akan mendukung proses pembelajaran jarak jauh dan mempermudah dalam penyebaran materi kepada peserta didik. Oleh karena itu, proses pembelajaran yang biasanya dilaksanakan di sekolah dengan tatap muka langsung dengan bapak/ibu guru dan temanteman tidak dapat dilakukan pada masa pandemi ini. Para mahasiswa diharuskan belajar dari rumah (BDR), untuk itu dosen juga diharuskan menyiapkan perangkat pembelajaran yang memungkinkan siswa untuk belajar dari rumah. Kondisi ini membuat dosen harus mengubah strategi belajar mengajarnya. Penggunaan metode pengajaran yang tepat maupun perilaku dan sikap dosen dalam mengelola proses belajar mengajar sangat dibutuhkan dalam pembelajaran selama program belajar dari rumah (BDR). Semua ini dilakukan untuk memberikan akses pembelajaran yang tidak terbatas ruang dan waktu kepada peserta didik selama diberlakukannya masa darurat Covid-19. 
Kondisi siswa dan guru yang tidak dapat bertemu secara langsung untuk menjaga social distancing dan physical distancing inilah yang membuat pembelajaran harus dilakukan melalui pembelajaran daring. Pada pembelajaran daring, kita mengenal ada istilah pembelajaran sinkron dan pembelajaran asinkron. Menurut Chaeruman (2017), dalam pembelajaran sinkron, siswa dan guru berada di tempat yang sama pada waktu yang sama. Ini mirip dengan kelas tatap muka. Salah satu contoh pembelajaran sinkron adalah ketika siswa dan guru berpartisipasi dalam kelas melalui aplikasi web conference. Ini menciptakan ruang kelas virtual yang memungkinkan mahasiswa mengajukan pertanyaan dan para dosen menjawab secara instan. Secara keseluruhan, pembelajaran yang sinkron memungkinkan mahasiswa dan dosen untuk berpartisipasi dan belajar secara langsung dan terlibat dalam diskusi langsung. Sedangkan pembelajaran asinkron adalah pendekatan belajar mandiri dengan interaksi asinkron untuk mendorong pembelajaran. Email, papan diskusi online, Wikipedia, dan blog adalah sumber daya yang mendukung pembelajaran asinkron. Beberapa kegiatan pembelajaran asinkron yang umum adalah berinteraksi dengan Learning Management System (LMS), berkomunikasi menggunakan email, memposting di forum diskusi dan membaca artikel. Selain itu, penting untuk menjaga umpan balik tepat waktu dan komunikasi yang jelas untuk melibatkan siswa dalam pembelajaran. Secara keseluruhan, pembelajaran asinkron memberikan keuntungan seperti kenyamanan, fleksibilitas, lebih banyak interaksi dan untuk melanjutkan tanggung jawab kehidupan pribadi dan profesional. Perbedaan antara pembelajaran sinkron dan asinkron adalah bahwa pembelajaran sinkron melibatkan sekelompok siswa yang terlibat dalam pembelajaran pada saat yang sama mirip dengan kelas virtual sedangkan pembelajaran asinkron melibatkan pembelajaran yang berpusat pada siswa mirip dengan pendekatan belajar mandiri yang mirip dengan pendekatan belajar mandiri dengan sumber belajar online yang diperlukan.

Konsep belajar dari rumah (BDR) di mahasiswa semester II program studi Pendidikan Olahraga dan Kesehatan dilaksanakan secara sinkron dan asinkron. Pelaksanaan pembelajaran dengan sinkron dilaksanakan satu kali dalam 1 minggu dengan melalui google meet/zoom meeting dan sisanya dilaksanakan secara asinkron dengan memanfaatkan layanan google classroom.

Berdasarkan kondisi yang terjadi selama pandemi covid -19 serta kajian dari beberapa teori di atas maka tujuan penelitian ini adalah menganalisis efektivitas pelaksanaan proses Belajar dari Rumah (BDR) selama pandemi Covid-19 pada mahasiswa semester II program studi Pendidikan Olahraga dan Kesehatan.

\section{METODE PENELITIAN}

Penelitian ini menggunakan jenis penelitian kombinasi (mixed methods) kualitatif dan kuantitatif. Metode penelitian kombinasi adalah suatu metode penelitian yang mengkombinasikan atau menggabungkan antara metode kuantitatif dan metode kualitatif untuk digunakan secara bersama-sama dalam suatu kegiatan penelitian, sehingga diperoleh data yang lebih komprehensif, valid, reliabel dan obyektif. Melalui kombinasi dua metode, maka data yang diperoleh dari penelitian akan lebih valid, karena data yang kebenarannya tidak dapat divalidasi dengan metode kuantitatif akan divalidasi dengan metode kualitatif atau sebaliknya (Sugiyono, 2017).

Didasari permasalahan yang akan diteliti yaitu menganalisis efektivitas pelaksanaan proses Belajar dari Rumah (BDR) selama pandemi Covid-19 pada mahasiswa semester II program studi Pendidikan Olahraga dan Kesehatan maka penelitian ini menggunakan jenis penelitian kombinasi kuantitatif kualitatif. Penelitian kuantitatif dilakukan untuk melihat tingkat efektivitas belajar mahasiswa penelitian kualitatif untuk mengetahui respon mahasiswa terhadap pelaksanaan belajar dari rumah. Hal ini dilakukan secara sepadan, tidak terlalu dominan pada salah satunya.

Teknik pengumpulan data yang digunakan adalah kuisioner menggunakan angket yang diberikan kepada siswa setiap satu bulan sekali untuk mendapatkan gambaran pelaksanaan BDR selama bulan tersebut. Dalam analisis kuantitatif ini variabel penelitian disusun secara deskriptif dengan menilai prosentase pencapaian 
standar dalam bentuk tabel. Teknik analisis data yang digunakan adalah milik Miles and Huberman. Miles and Huberman (Sugiyono, 2017) mengemukakan bahwa aktivitas dalam analisis data kualitatif dilakukan secara interaktif dan berlangsung secara terus menerus sampai tuntas, sehingga datanya sudah jenuh. Aktivitas dalam analisis data, yaitu: data reduction, data display, conclusion drawing/verification.

Data yang diperoleh disajikan dalam bentuk tabel dan dideskripsikan. Pendeskripsian data dilakukan dalam bentuk persen.

$$
\%=\frac{\text { Jumlah Bagian }}{\text { Jumlah Keseluruhan }} X 100 \%
$$

Perhitungan nilai rata-rata dilakukan dengan menjumlahkan seluruh nilai data suatu kelompok sampel, kemudian dibagi dengan jumlah sampel tersebut. Jadi jika suatu kelompok sampel acak denga jumlah sampel n, maka dapat dihitung rata-rata dari sampel tersebut sebagai berikut.

$$
\overline{\mathrm{X}}=\sum_{i=1}^{n} x_{i}
$$

Sumber data : (Sugiyono, 2017)

\section{HASIL DAN PEMBAHASAN}

Penelitian dilaksanakan di semester II program studi Pendidikan Olahraga dan Kesehatan pada bulan April 2021. Jumlah responden sebanyak 21 mahasiswa dari 42 mahasiswa seluruhnya.

Penelitian dilakukan dengan memberikan angket kepada mahasiswa melalui $M s 365$ form yang berisi 9 pertanyaan. Adapun kisi - kisi pertanyaan tersebut dapat dilihat pada tabel 1 berikut.

Tabel 1. Kisi - kisi Angket respon siswa Terhadap Belajar Jarak Jauh

\begin{tabular}{cccc}
\hline No & Indikator & $\begin{array}{c}\text { Item } \\
\text { Pertanyaan }\end{array}$ & No butir \\
\hline 1 & Efektivitas BDR & 1 & 1 \\
2 & Akses BDR & 1 & 2 \\
3 & Reaksi tugas BDR & 1 & 3 \\
4 & Materi BDR & 1 & 6 \\
5 & Media BDR & 2 & 4,5 \\
6 & Evaluasi BDR & 2 & 7,9 \\
7 & Kejelasan instruksi & 1 & 8 \\
\hline
\end{tabular}

(Sumber : Data sekunder, 2021)

Berdasarkan hasil respon angket yang diberikan melalui email masing-masing responden didapatkan.
1. Apakah kamu bisa mengikuti pembelajaran jarak jauh melalui google classroom dengan baik? Dari item pertanyaan ke -1 ini jawaban mahasiswa adalah $90 \%$ menjawab bisa mengikuti dengan baik dan $10 \%$ menjawab hanya sedikit mengikuti.

2. Apakah kamu bisa mengakses Google Classroom untuk mengetahui materi PJJ setiap harinya? Dari item pertanyaan ke -2 ini jawaban mahasiswa adalah $70 \%$ menjawab mahasiswa, 30\% menjawab teman.

3. Apakah reaksi kalian saat menerima materi PJJ yang disampaikan dosen melalui Google Classroom? Dari item pertanyaan ke -6 ini jawaban mahasiswa adalah $73 \%$ menjawab langsung mengerjakan dan $6 \%$ menjawab menunda mengerjakan.

4. Apakah menurut kalian video pembelajaran yang dibuat itu membantu memahami materi pelajaran? Dari item pertanyaan ke -4 ini jawaban mahasiswa adalah $81 \%$ menjawab ya saya bisa menyelesaikan tugas dengan baik, $19 \%$ menjawab tidak.

5. Apakah kalian selalu menyimak video pembelajaran/PPT yang diberikan dosen? Dari item pertanyaan ke - 5 ini jawaban siswa adalah $76 \%$ menjawab ya dan $5 \%$ menjawab tidak, dan $19 \%$ menjawab kadangkadang.

6. Bagaimana pendapat kalian tentang video pembelajaran mata kuliah Bahasa Indonesia yang dosen buat? Dari item pertanyaan ke 6 ini jawaban mahasiswa adalah $75 \%$ menjawab menarik dan $17 \%$ menjawab biasa saja dan $8 \%$ menjawab membosankan.

7. Untuk pertanyaan berupa kuis, aplikasi apa yang lebih kamu sukai? Dari item pertanyaan ke -7 ini jawaban mahasiswa adalah 50\% menjawab google form dan $46 \%$ menjawab quizizz dan 4\% menjawab MS 365.

8. Apakah kalian selalu membaca dulu instruksi yang dosen berikan di Google Classroom? Dari item pertanyaan ke -9 ini jawaban mahasiswa adalah $76 \%$ menjawab ya dan $5 \%$ menjawab tidak dan $19 \%$ menjawab kadang.

9. Bagaimana pandanganmu terhadap tugastugas PJJ? Dari item pertanyaan ke -8 ini jawaban mahasiswa adalah $24 \%$ menjawab wajib diselesaikan untuk melatih karakter disiplin dan tanggung jawab saya dan $18 \%$ 
menjawab wajib diselesaikan karena dengan begini saya bisa tetap belajar, $24 \%$ menjawab wajib diselesaikan sebagai tugas agar mendapat nilai baik, $24 \%$ menjawab wajib diselesaikan untuk menambah wawasan saya, dan $10 \%$ menjawab tidak wajib diselesaikan karena hanya sebagai pengisi waktu saja sambil menunggu pembelajaran tatap muka kembali.

Selanjutnya untuk mengetahui hasil efektifitas Belajar dari Rumah (BDR) maka hasil analisis setiap butir pertanyaan diambil rata - rata pernyataan yang bersifat positif dan dikonversi pada kriteria keefektifan yang telah ditentukan. Terdapat penafsiran dan pengambilan keputusan tentang hasil analisis data terhadap penelitian dapat yang dikonversi dengan menggunakan kriteria sebagai berikut.

Tabel 2. Konversi Tingkat Pencapaian dan Kualifikasi Keefektifan

\begin{tabular}{ccc}
\hline No. & Kriteria & Kualifikasi \\
\hline 1 & $80 \%-100 \%$ & Sangat baik \\
2 & $60 \%-79 \%$ & Cukup baik \\
3 & $50 \%-59 \%$ & Kurang baik \\
4 & $<49 \%$ & Tidak baik \\
\hline
\end{tabular}

Berdasarkan tabel konversi keefektifan pelaksanaan belajar dari rumah (BDR) pada mahasiswa semester II program studi Pendidikan Olahraga dan Kesehatan Tahun Ajaran 2020/2021 maka data yang diperoleh dihitung rata - rata setiap indikator untuk dianalisa berdasarkan kualifikasi keefektifan. Analisa hasil pengisian angket pelaksanaan BDR pada mahasiswa semester II program studi Pendidikan Olahraga dan Kesehatan Tahun Ajaran 2020/2021 disajikan pada tabel 3 berikut ini.

Tabel 3. Analisa Hasil Pengisian Angket pelaksanaan BDR pada mahasiswa semester II program studi Pendidikan Olahraga dan Kesehatan

\begin{tabular}{|c|l|l|l|}
\hline No. & Indikator & $\begin{array}{c}\text { Hasil rata- } \\
\text { rata }\end{array}$ & $\begin{array}{l}\text { Kualifikasi } \\
\text { Keefektifan }\end{array}$ \\
\hline 1 & Efektivitas & $95 \%$ & $\begin{array}{l}\text { Sangat } \\
\text { baik }\end{array}$ \\
\hline 2 & Akses & $70 \%$ & $\begin{array}{l}\text { Cukup } \\
\text { baik }\end{array}$ \\
\hline 3 & Reaksi tugas & $73 \%$ & $\begin{array}{l}\text { Cukup } \\
\text { baik }\end{array}$ \\
\hline 4 & Materi & $86 \%$ & Sangat \\
\hline
\end{tabular}

\begin{tabular}{|c|l|l|l|}
\hline 5 & Media & $77 \%$ & $\begin{array}{l}\text { baik } \\
\text { bakup }\end{array}$ \\
\hline 6 & Evaluasi & $48 \%$ & Tidak baik \\
\hline 7 & $\begin{array}{l}\text { Kejelasan } \\
\text { instruksi }\end{array}$ & $76 \%$ & $\begin{array}{l}\text { Cukup } \\
\text { baik }\end{array}$ \\
\hline
\end{tabular}

Sumber: Data Sekunder diolah, 2021

\section{PEMBAHASAN}

Berdasarkan hasil penelitian yang dilakukan dengan melakukan pengisian kuisioner melalui Ms. 365 form maka didapatkan hasil bahwa secara umum pelaksanaan pembelajaran dari rumah pada mahasiswa semester II program studi Pendidikan Olahraga dan Kesehatan berjalan cukup efektif dengan persentase 60-79\%. Tapi jika dianalisis lebih dalam efektivitas pelaksanaan BDR ini berjalan cukup efektif dikarenakan mahasiswa sudah terbiasa dengan gawai sehingga dalam akses pembelajaran mereka tidak memiliki masalah yang berarti, hanya saja akses pembelajaran daring menjadi tidak terlalu tinggi karena rata - rata mahasiswa semester II program studi Pendidikan Olahraga dan Kesehatan memegang gawai sendiri. Keefektifan penggunaan gawai dalam pembelajaran selaras dengan yang disampaikan oleh Pribowo (2020) yang menjelaskan tentang perilaku anak dan remaja dalam menggunakan internet mencatat sebanyak 84 persen dari jumlah total seluruh rakyat Indonesia adalah pengguna telepon seluler. Sebanyak 52 persen dari seluruh pengguna telepon seluler tersebut adalah anak - anak dan remaja. Penelitian ini juga menemukan bahwa 98 persen dari anakanak dan remaja yang disurvei tahu tentang internetdan 79,5 persen diantaranya adalah pengguna internet.

Selain akses internet berdasarkan hasil respon kuisioner, efektifitas pemahaman materi yang dimiliki mahasiswa melalui belajar BDR sangat baik hal ini didukung oleh sarana dan prasarana belajar yang disediakan oleh kampus dan dosen. Dosen menyediakan media elearning berupa materi yang lengkap dan mudah diakses oleh siswa melalui laman LMS Google Classroom. Dosen juga menyediakan video sebagai media yang mendukung penjelasan materi kepada siswa. Efektivitas video di dalam 
pembelajaran adalah sebagai suplemen untuk menarik perhatian dan minat belajar siswa.

Kelebihan Video dalam pembelajaran diungkap oleh Hamzah B. Uno \& Nina Lamatenggo (2011) yang menyatakan bahwa video pembelajaran memiliki beberapa kelebihan yaitu video dapat memanipulasi waktu dan ruang, siswa dapat diajak melanglang buana ke mana saja walaupun dibatasi dengan ruang kelas. Video juga dapat menampilkan objek-objek yang terlalu kecil, terlalu besar, berbahaya, atau bahkan tidak dapat dikunjungi oleh siswa. Kemampuan media video juga dapat diandalkan pada bidang studi yang mempelajari keterampilan motorik dan melatih kemampuan kegiatan.

Adapun hasil kuisioner pelaksanaan pembelajaran BDR yang memiliki efektifitas tidak baik dengan kriteria sebesar 48\%adalah pada proses evaluasi. Mahasiswa merasa evaluasi dalam bentuk tugas yang diberikan terlalu banyak dan memberatkan. Pada proses BDR memang banyak materi yang disampaikan melalui LKS hal tersebut bertujuan untuk meningkatkan kemampuan berpikir kritis siswa. Namun mahasiswa menganggap tugas yang diberikan merupakan tes penilaian hasil belajar sehingga siswa merasa berat dalam menyelesaikannya. Sebenarnya tugas yang diberikan oleh guru itu adalah sebuah proses yang sengaja dibuat oleh guru untuk menilai proses pembelajaran, bukan hanya untuk menilai capaian akhir saja. Dalam hal ini ada perbedaan persepsi dari siswa dan guru terhadap jalannya proses evaluasi.

Perbedaan persepsi itu timbul karena kurangnya komunikasi dua arah antara guru dan siswa. Dalam proses pembelajaran secara asinkron. Siswa kurang aktif dalam memberikan respon terhadap instruksi yang diberikan oleh guru. Begitu juga ketika proses pembelajaran secara sinkron dilakukan. Kebanyakan hanya guru saja yang aktif berbicara. Siswa cenderung malu mengungkapkan pendapatnya secara terbuka melalui media web conference yang dilaksanakan untuk pembelajaran daring secara sinkron.

Selain adanya persepsi mengenai proses evaluasi yang berbeda, beberapa faktor yang ditemukan juga menjadi penyebab dari ketidakefektifan proses belajar

dari rumah adalah karena banyaknya distruction/gangguan ketika proses belajar berlangsung seperti game/TV yang membuat siswa kurang focus dalam pelaksanaan proses evaluasi pembelajaran. Mahasiswa cenderung ingin cepat selesai. Kurangnya komunikasi secara efektif antara dosen dengan mahasiswa serta mahasiswa dengan mahasiswa lainnya menyebabkan proses pelaksanaan belajar dari rumah ini, lama kelamaan menjadi membosankan bagi mahasiswa. Beberapa hal lain yang juga menyebabkan proses belajar jadi rumah ini menjadi kurang efektif adalah adanya kendala aplikasi yang rumit atau tidak biasa digunakan mahasiswa, baik dosen maupun mahasiswa kurang menguasai platform media pembelajaran daring yang digunakan.

Adanya kendala mengenai proses evaluasi dalam pembelajaran daring yang dirasa terlalu berat, sejalan dengan temuan Mustakim, (2020) mengenai efektivitas pembelajaran daring menggunakan media online selama Covid-19, bahwa untuk meningkatkan kualitas pembelajaran daring selama pandemi covid-19, maka pemberian materi pembelajaran sebaiknya disampaikan secara ringkas meminimalisir mengirim materi dalam bentuk video berdurasi panjang untuk menghemat kuota, memilih media berupa video dengan menggunakan bahasa yang mudah dipahami, tetap memberikan materi sebelum penugasan namun dalam pemberian tugas hendaknya tidak terlalu banyak dan soal hendaknya lebih variatif, serta pemberian tugas harus disertakan dengan instruksi yang jelas.

\section{SIMPULAN DAN SARAN}

Berdasarkan hasil dan pembahasan yang telah dibahas pada pembahasan, kesimpulan yang dapat diambil adalah bahwa pelaksanaan Belajar dari Rumah (BDR) untuk mahasiswa semester II program studi Pendidikan Olahraga dan Kesehatan berlangsung cukup efektif. Siswa bisa mengakses sendiri materi pembelajaran yang disampaikan dosen dengan menggunakan gawainya. Penggunaan video pembelajaran juga cukup menarik minat mahasiswa untuk menyelesaikan setiap tahap pembelajaran dan 
memahami materi dengan baik, namun ada ketidakefektifan pada proses evaluasi.

Saran dari peneliti bagi dosen, dosen dituntut harus mampu mendesain kegiatan belajar dari rumah secara lebih ringan, kreatif namun efektif, dengan memanfaatkan

perangkat atau media yang tepat sesuai dengan materi yang hendak disampaikan. Jenis tugas yang diberikan pun harus dirancang sedemikian hingga mahasiswa tetap semangat dalam belajar secara daring dan tidak menjadi beban psikis. Walaupun kegiatan belajar dari rumah dengan sistem daring akan memberikan kesempatan lebih luas dalam mengeksplorasi materi yang akan diajarkan, namun dosen harus mampu memilih dan membatasi sejauh mana cakupan materinya dan aplikasi yang cocok pada materi dan metode belajar yang digunakan. Dosen juga perlu lebih memberi pemahaman kepada mahasiswa bahwa tugas yang diberikan itu bukanlah sebuah beban yang menjadi kewajiban untuk diselesaikan, tetapi adalah sebuah proses yang harus dilalui untuk mempermudah mahasiswa dalam memahami materi.

\section{DAFTAR PUSTAKA}

Arsyad, A. (2011). Media Pembelajaran. Jakarta: Rajawali Pers.

Chaeruman, U. A. (2017). PEDATI Model Sistem Pembelajaran Blended, Panduan Merancang Mata Kuliah Daring, SPADA Indonesia. Jakarta: Direktorat Pembelajaran KEMRISTEKDIKTI.

Hamalik, O. (2005). Perencanaan Pengajaran Berdasarkan Pendekatan Sistem. Bandung: Bumi Aksara

Uno, H.B, \& Lamatenggo, Nina. (2011). Teknologi Komunikasi dan Informasi Pembelajaran. Jakarta: Bumi Aksara.

Uno, H.B, (2008). Perencanaan Pembelajaran. Jakarta: PT Bumi Aksara.

Ibrahim, D. S., \& Suardiman, S. P. (2014). Pengaruh Penggunaan E-Learning Terhadap Motivasi dan Prestasi Belajar Matematika Siswa SDN Tahunan Yogyakarta. Jurnal Prima Edukasia, 2(1), 66 diakses pada 24 Agustus 2020.

Iskandarwassid \& Sunendar, D (2011) Strategi Pembelajaran Bahasa. Bandung. PT. Remaja Rosdakarya.
Kemendikbud. (2020). Pedoman Penyelenggaraan Belajar dari Rumah. www.kemdikbud.go.id. diakses pada 19 Agustus 2020.

Lestari, I. (2013). Pengembangan bahan ajar berbasis Kompetensi Sesuai dengan Kurikulum Tingkat Satuan Pendidikan . Padang: Akadenia Permata.

Mulyasa, E. (2006). Kurikulum Tingkat Satuan Pendidikan. Bandung: PT. Remaja Rosdakarya.

Mustakim. (2020). Efektivitas Pembelajaran Daring Menggunakan Media Online Selama Pandemi Covid-19 pada Mata Pelajaran Matematika.

Journal.uinalauddin.ac.id/index.php/alasma/artic le/view/13646 diakses pada 23 Agustus 2020.

Prastowo, A. (2012). Metode Penelitian Kualitatif dalam Prespektif Rancangan Penelitian. Yogyakarta: ArRuzz Media.

Pribowo, F. S. (2017). Pengembangan Bahan Ajar Mata Kuliah IPA Berbasis Pendekatan Scientific Approach. Pedagogia.

Rooijakkers, A. (1991). Mengajar dengan Sukses: Petunjuk untuk Merencanakan dan Menyampaikan Pengajaran. Jakarta: PT Presindo.

Rustaman. (2001). Keterampilan Bertanya dalam Pembelajaran IPA. dalam Handout Bahan Pelantikan Guru-Guru IPA SLTP Se-Kota Bandung di PPG IPA. Jakarta: Depdiknas.

Sudjana, N. (2010). Penilaian Proses Belajar Mengajar. Bandung: PT. Remaja Rosdakarya.

Sugiyono. 2017. Metode Penelitian Kuantitatif, Kualitatif, dan R\&D. Bandung: Alfabeta.

Syaiful, B. D. (2013). Strategi belajar mengajar. Jakarta: Rineka Cipta.

Wardhana, Y. (2010). Teori belajar dan mengajar. Bandung: Pribumi Mekar.

Winkel. (1991). Psikologi Pengajaran, Jakarta: Gramedia. 